\title{
Characterization and Neutron Shielding Behavior of Dehydrated Magnesium Borate Minerals Synthesized via Solid-State Method
}

\author{
Azmi Seyhun Kipcak, ${ }^{1}$ Derya Yilmaz Baysoy, ${ }^{2}$ Emek Moroydor Derun, ${ }^{1}$ and Sabriye Piskin ${ }^{1}$ \\ ${ }^{1}$ Chemical Engineering Department, Faculty of Chemical and Metallurgical Engineering, Yildiz Technical University, \\ Davutpasa Street, No. 127, Esenler, 34210 Istanbul, Turkey \\ ${ }^{2}$ Environmental Engineering Department, Faculty of Civil Engineering, Yildiz Technical University, Davutpasa Street No. 127, \\ Esenler, 34210 Istanbul, Turkey
}

Correspondence should be addressed to Emek Moroydor Derun; moroydor@gmail.com

Received 14 February 2013; Revised 2 October 2013; Accepted 2 October 2013

Academic Editor: Kunpeng Wang

Copyright (C) 2013 Azmi Seyhun Kipcak et al. This is an open access article distributed under the Creative Commons Attribution License, which permits unrestricted use, distribution, and reproduction in any medium, provided the original work is properly cited.

\begin{abstract}
Magnesium borates are one of the major groups of boron minerals that have good neutron shielding performance. In this study, dehydrated magnesium borates were synthesized by solid-state method using magnesium oxide $(\mathrm{MgO})$ and boron oxide $\left(\mathrm{B}_{2} \mathrm{O}_{3}\right)$, in order to test their ability of neutron shielding. After synthesizing the dehydrated magnesium borates, characterizations were done by X-ray Diffraction (XRD), fourier transform infrared (FT-IR), Raman spectroscopy, and scanning electron microscopy (SEM). Also boron oxide $\left(\mathrm{B}_{2} \mathrm{O}_{3}\right)$ contents and reaction yields (\%) were calculated. XRD results showed that seven different types of dehydrated magnesium borates were synthesized. $1000^{\circ} \mathrm{C}$ reaction temperature, 240 minutes of reaction time, and $3: 2,1: 1$ mole ratios of products were selected and tested for neutron transmission. Also reaction yields were calculated between 84 and $88 \%$ for the $3: 2$ mole ratio products. The neutron transmission experiments revealed that the $3: 2$ mole ratio of $\mathrm{MgO}_{\mathrm{O}}$ to $\mathrm{B}_{2} \mathrm{O}_{3}$ neutron transmission results $(0.618-0.655)$ was better than the ratio of $1: 1(0.772-0.843)$.
\end{abstract}

\section{Introduction}

Dehydrated magnesium borates are well-known metal borates that have many chemical formulas such as, $\mathrm{Mg}_{2} \mathrm{~B}_{2} \mathrm{O}_{5}$ (suanite), $\mathrm{MgB}_{3} \mathrm{~B}_{2} \mathrm{O}_{6}$ (kotoite), and $\mathrm{MgB}_{4} \mathrm{O}_{7}$ [1]. They owe very important properties like high heat-resisting, antiwear and anticorrosion materials, super mechanical strength, super insulation, lightweight, high strength, and high coefficient of elasticity [2]. Magnesium borates have many potential applications involving catalysts for the conversion of hydrocarbons [3], the thermoluminescence phosphor [4], and as fused cast refractory that possesses corrosion-erosion resistance in basic oxygen steel making environments and high degree of thermal shock resistance [5].

The synthesis of magnesium borates can be divided into two according to their structures, such as; hydrated or dehydrated. For the production of hydrated magnesium borates, hydrothermal method can be used. Thermal or solidstate (solid-solid reaction type) method [6] or chemical deposition method [7] can be applied for the production of dehydrated magnesium borates. Various synthesis methods for preparation of dehydrated magnesium borates have been proposed up to now. In recent years, several nanostructure forms of dehydrated magnesium borates, such as nanorods $[1,2,7]$ and nanowhiskers [8], have been synthesized through high temperature solid-state synthesis method, respectively. Došler et al., Qasrawi et al., and Elssfah et al. synthesized $\mathrm{Mg}_{2} \mathrm{~B}_{2} \mathrm{O}_{5}$ type magnesium borate where Došler et al. used $\mathrm{MgO}$ and $\mathrm{B}_{2} \mathrm{O}_{3}$ and Qasrawi et al. and Elssfah et al. used magnesium hydroxide $\left(\mathrm{Mg}(\mathrm{OH})_{2}\right)$ and boric acid $\left(\mathrm{H}_{3} \mathrm{BO}_{3}\right)$ $[2,9,10]$. Li et al., also synthesized $\mathrm{Mg}_{2} \mathrm{~B}_{2} \mathrm{O}_{5}$ type magnesium borate but they used magnesium chloride hexahydrate $\left(\mathrm{MgCl}_{2} \cdot 6 \mathrm{H}_{2} \mathrm{O}\right)$ and sodium borohydrate $\left(\mathrm{NaBH}_{4}\right)$ as starting materials [1]. Zhang et al. synthesized $\mathrm{Mg}_{3} \mathrm{~B}_{2} \mathrm{O}_{6}$ with a particle size of $100-300 \mathrm{~nm}$ [11]. Zeng et al. synthesized $\mathrm{Mg}_{2} \mathrm{~B}_{2} \mathrm{O}_{5}$ from hydrated magnesium borate minerals [12].

Many countries around the world, especially USA and France, use boron compounds as a shielding material in 
nuclear reactor technologies. A number of studies have been conducted in the area of nuclear shielding, both in Turkey and in the world [13]. Some materials [3] were constructed and investigated at the area of nuclear shielding namely polyboron [14], neutron filter [15], thermal neutron radiation shield [16], ceramic shield material containing boron carbide $\left(\mathrm{B}_{4} \mathrm{C}\right)$ [17], and biological shielding material [18]. In these studies the materials like $\mathrm{B}_{4} \mathrm{C}, \mathrm{B}_{2} \mathrm{O}_{3}$, iron $(\mathrm{Fe})$, lead $(\mathrm{Pb})$, and bismuth $(\mathrm{Bi})$ were investigated. Kipcak investigated the usability of boron minerals as a neutron shielding material and conducted a study including the shielding behavior of boron minerals against neutron radiation and twelve year performance of neutron transmission, he used only boron minerals as a shield material [13, 19-21].

The aim of the article can be divided into two parts, where in part one high crystalline dehydrated magnesium borate synthesis via solid-state method was studied. In the literature, the studies involving dehydrated magnesium borate formation were lacking reaction yields and crystalline scores. So, it is necessary to develop a cost friendly with a high reaction yield and effective method for the production of high crystalline dehydrated magnesium borates. After the successful synthesis of dehydrated magnesium borates the techniques of XRD, FT-IR, Raman Spectroscopy, and SEM were used to characterize the obtained minerals. Also $\mathrm{B}_{2} \mathrm{O}_{3}$ contents were determined by titration and reaction yields were calculated. In the second phase the neutron shielding behavior of dehydrated magnesium borates against neutron radiation were tested, where neutron radiation experiments were conducted with ${ }^{241} \mathrm{Am}$-Be source moderated in howitzer. In this analysis high crystalline type of minerals is important for the neutron shielding studies since crystal structures show the homogeneous radiation shielding performance and repeatability of the experiments.

\section{Materials and Methods}

2.1. Preparation of the Reactants. $\mathrm{B}_{2} \mathrm{O}_{3}$ was supplied from Kirka Boron Management Plant (EtiMine Kirka Boron Works) in Eskisehir, Turkey, and $\mathrm{MgO}$ was supplied from Merck Chemicals. $\mathrm{B}_{2} \mathrm{O}_{3}$ was crushed, grinded, and sieved to +200 meshes with agate mortar. $\mathrm{MgO}$ was used without being subjected to any physical process. Then these reactants were taken for identification analysis, which was made by Philips PANanalytical XRD, where X-rays were produced from $\mathrm{Cu}$ $\mathrm{K} \alpha$ tube at the parameters of $45 \mathrm{kV}$ and $40 \mathrm{~mA}$.

2.2. Solid-State Synthesis of Dehydrated Magnesium Borates. Different mole ratios of $\mathrm{MgO}: \mathrm{B}_{2} \mathrm{O}_{3}$ were selected as $2: 1$, $3: 2,1: 1,1: 2$, and $1: 4$. These mole ratios were determined after some preliminary experiments. Prepared mixtures were pressed (10 tones) with Manfredi OL57 hydraulic press. After the pelletization process the minerals were subjected to $600^{\circ} \mathrm{C}$ through $1000^{\circ} \mathrm{C}$ temperatures with Protherm MOS 180/4 model high temperature furnace. The temperature increment was selected as $10^{\circ} \mathrm{C} / \mathrm{min}$ and the experimental time is set as 240 minutes for the temperatures of $600^{\circ} \mathrm{C}$ and $700^{\circ} \mathrm{C}$. For $800^{\circ} \mathrm{C}, 900^{\circ} \mathrm{C}$, and $1000^{\circ} \mathrm{C}$, the experiment times were set as
30, 60, and 240 minutes. All reactions were conducted in a ceramic crucible whose inside was coated with $\mathrm{Al}_{2} \mathrm{O}_{3}$. The reaction atmosphere was used as air. After the reaction, the obtained solid particles were crashed and grinded.

2.3. Characterizations of the Synthesized Products. The identification and characterization of the synthesized products were done with the parameters that are the same as the one conducted at Section 2.1 by XRD technique. Perkin Elmer brand FT-IR technique with Universal ATR sampling accessory-diamond/ZnSe was used with $1800-$ $650 \mathrm{~cm}^{-1}$ measurement range and $4 \mathrm{~cm}^{-1}$ resolution. Scan number was set to 4 . To support the FT-IR results, Raman spectroscopy of Perkin Elmer Brand, Raman Station 400 F, was used with the exposure time of 4 seconds, number of exposures of $4,1800-250 \mathrm{~cm}^{-1}$ measurement range, and $2 \mathrm{~cm}^{-1}$ data interval. Full (100\%) laser power was used and "auto baseline" option was also selected during the experiments.

In order to investigate and analyze the surface morphology SEM analysis was conducted. CamScan Apollo brand 300 Field-Emission SEM was used at $20 \mathrm{kV}$ with back scattering electron (BEI) detector. Magnifications were set to 1000 and 5000 .

Since boron is the well-known neutron absorber, it was important to determine the $\mathrm{B}_{2} \mathrm{O}_{3}$ content of the synthesized minerals. $\mathrm{B}_{2} \mathrm{O}_{3}$ analyses were made and calculated by using the procedure given in Moroydor Derun et al. [22] in this procedure, $1 \mathrm{~g}$ of synthesized mineral was dissolved in $3 \mathrm{~mL}$ of $37 \% \mathrm{HCl}$ and then diluted to $100 \mathrm{~mL}$. Pure $\mathrm{H}_{3} \mathrm{BO}_{3}$ obtained from Merck Chemicals was prepared in the same manner and was used as the reference material. Then, $\mathrm{B}_{2} \mathrm{O}_{3}$ amounts were determined through acid-base titration with a Mettler DL-25 titrator.

Reaction yields were also calculated with the method given in Moroydor Derun et al. [22] and Fogler [23]. Reaction yields are based on molar flow rates, the overall yield, $Y_{D}$, is defined as the ratio of moles of product formed at the end of the reaction, $N_{D}$ is the number of moles of the key reactant (MgO), $A$ that have been consumed, and $N_{A 0}$ and $N_{A}$ are the initial and final moles of consumed reactant, respectively. For a batch system the overall yield is given in the following $[22,23]$ :

$$
Y_{D}=\frac{N_{D}}{N_{A 0}-N_{A}} .
$$

2.4. Neutron Shielding Study. Neutron transmission experiments were conducted in Cekmece Nuclear Research and Training Center (CNAEM). For the experimental system ${ }^{241} \mathrm{Am}$-Be source moderated in howitzer that has $74 \mathrm{GBq}$ activity was used. The neutrons in this source had an average and maximum energy of $4.5 \mathrm{MeV}$ and $12 \mathrm{MeV}$, respectively. Neutron counts were measured by $\mathrm{BF}_{3}$ neutron detector (diameter: $2.54 \mathrm{~cm}$, length: $28 \mathrm{~cm}$ ) and counter.

With the experimental setup mentioned, the minerals which were synthesized using $\mathrm{MgO}$ and $\mathrm{B}_{2} \mathrm{O}_{3}$ with $1000^{\circ} \mathrm{C}$ reaction temperature, 240 minutes of reaction time, and $3: 2$ and 1:1 mole ratios were tested for neutron radiation. 
For the neutron radiation experiments 10, 15, and $25 \mathrm{~g}$ of minerals were taken and mixed with wax $\left(\mathrm{C}_{3} \mathrm{H}_{8} \mathrm{O}_{7} \mathrm{~N}_{7}\right)(10 \%$ by weight). Wax was used as an adhesive. The mixtures were mixed five minutes in the agate mortar. Then the mixtures were pelleted with $(25 \mathrm{MPa})$ hydraulic press, using the $40 \mathrm{~mm}$ molding set.

For each sample, the neutrons passing through the pelleted minerals were counted $(I)$ by neutron detector. Then the same procedure was conducted without using the pelleted minerals in order to measure the collimated neutrons $\left(I_{0}\right)$. The experiments were conducted with 4 parallels in order to minimize the experimental errors. Total neutron transmission (2) values and total macroscopic cross-sections $\left(\Sigma_{t}\right)$ (3) were calculated with the Beer-Lambert law, for the energy value of $4.5 \mathrm{MeV}$, where " $x$ " is the thickness of the minerals

$$
\begin{gathered}
\text { Neutron transmission }=\frac{I}{I_{0}}, \\
I=I_{0} \times e^{-\Sigma_{t} x} .
\end{gathered}
$$

\section{Results and Discussion}

3.1. X-Ray Diffraction Results. The raw materials used in the solid-state experiments were analyzed by XRD and $\mathrm{MgO}$ was found as "periclase $[\mathrm{MgO}]$ " with a reference code of "01-0772179 ". $\mathrm{B}_{2} \mathrm{O}_{3}$ was found as the mixture of "boron oxide $\left[\mathrm{B}_{2} \mathrm{O}_{3}\right]$ " and "boron oxide $\left[\mathrm{BO}_{2}\right]$ " with the reference codes of "00-0060297" and "01-088-2485," respectively.

In Table 1, XRD results of the synthesized dehydrated magnesium borates were shown. From the results it is seen that seven different types of dehydrated magnesium borates were formed. The crystallographic data obtained from XRD are given in Table 2. "K" code represents "kotoite" and $S^{1}$ and $S^{2}$ represent "suanite" minerals that have different lattice structures. And four different types of magnesium borates

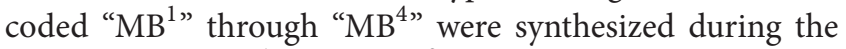
experiments. " $\mathrm{MB}^{1}$ " and " $\mathrm{MB}^{3}$ " coded minerals formula is the same as " $\mathrm{S}$ " and " $\mathrm{S}$ " but their lattice structures are different.

At the reaction temperature of $600^{\circ} \mathrm{C}$, the formation of dehydrated magnesium borates was started. At the ratio of 2:1 MgO was seen at the products as "periclase" which means that it reacts very little at that ratio; the same situation was seen at $700^{\circ} \mathrm{C}$ reaction temperature also. At the other ratios the formation of $\mathrm{S}^{1}, \mathrm{~S}^{2}$ and $\mathrm{MB}^{4}$ was seen but their crystal scores were too low, where perfect crystal structure of an element, mineral, or compound XRD score is equal to 100. $\mathrm{XRD}$ crystal scores were increased and a new mineral coded $\mathrm{MB}^{3}$ was synthesized at the reaction temperature of $700^{\circ} \mathrm{C}$ but their crystal scores were still low, which means that the crystallization was not enough at that temperature. At $800^{\circ} \mathrm{C}$ reaction time, major magnesium borate phase was seen as kotoite, "K." At this temperature and 30 minutes of reaction time the ratio of $1: 1$ had the greatest score among the other ratios. This score was increased to " 66 " at the reaction time of 60 minutes and finally became " 86 " at the reaction time of 240 minutes. The major phase of " $K$ " which was seen on $800^{\circ} \mathrm{C}$ was turned up a little to $\mathrm{MB}^{1}$ and $\mathrm{MB}^{2}$ at the reaction temperature $900^{\circ} \mathrm{C}$, because it was seen from the results that kotoite's crystal scores were decreased and the minor phase crystal scores were increased. At the highest reaction temperature of $1000^{\circ} \mathrm{C}$ minor phase scores of " $\mathrm{MB}^{1}$ "s were coming close to the " $\mathrm{K}$ " scores. The " $\mathrm{K}$ " scores did not change much with the increasing reaction time at $1000^{\circ} \mathrm{C}$ but " $\mathrm{MB}^{1 \text { " }}$ scores were increased. The highest crystal scores were obtained at the mole ratios of $3: 2$ and $1: 1$. For the comparison, XRD patterns of the dehydrated magnesium borates synthesized at $1000^{\circ} \mathrm{C}$ with the reaction times of 30 , 60, and 240 minutes are shown in Figure 1. It can be seen in Figure 1 that the ratios of $2: 1,3: 2$, and $1: 1$ patterns are smother than $1: 2$ and $1: 4$ ratios, meaning that better crystal structures were obtained at the first three ratios.

A three dimensional model graph of $\mathrm{K}$ and $\mathrm{MB}^{1}$ formations which were obtained from the score data by XRD was given in Figure 2. In this figure the $\mathrm{MgO}: \mathrm{B}_{2} \mathrm{O}_{3}$ mole ratios of " $3: 2$ " and " $1: 1$ " were used. At this graph $z$-, $y$ - and $x$-axes represents the $\mathrm{XRD}$ score, reaction temperature as ${ }^{\circ} \mathrm{C}$ and the reaction time as minutes, respectively. From this figure $\mathrm{K}$ and $\mathrm{MB}^{1}$ scores were the highest in $800^{\circ} \mathrm{C}$, and $1000^{\circ} \mathrm{C}$, respectively. According to the obtained graphs, there was no score of $\mathrm{MB}^{1}$ at the temperature of $800^{\circ} \mathrm{C}$.

3.2. FT-IR, Raman, SEM, $\mathrm{B}_{2} \mathrm{O}_{3}$ Results, and Reaction Yields. Obtained FT-IR and Raman spectra from the synthesized dehydrated magnesium borates were approximately the same, so only $1000^{\circ} \mathrm{C}$ reaction time and 240 minutes of reaction time results were given in Figures 3 and 4, respectively.

From the FT-IR spectrum, the peak value at around $1411 \mathrm{~cm}^{-1}$ represents the asymmetric stretching of three coordinate boron $\left[v_{\text {as }}\left(\mathrm{B}_{(3)}-\mathrm{O}\right)\right]$. The peaks between 1283$1285 \mathrm{~cm}^{-1}$ represent also $v_{\text {as }}\left(\mathrm{B}_{(3)}-\mathrm{O}\right)$. Bending of $\mathrm{B}-\mathrm{O}-\mathrm{H}$ $[\delta(\mathrm{B}-\mathrm{O}-\mathrm{H})]$ was formed at the peaks between 1123 and $1125 \mathrm{~cm}^{-1}$. The peak at around $883 \mathrm{~cm}^{-1}$ is the symmetric stretching of three coordinate boron $\left[v_{\mathrm{as}}\left(\mathrm{B}_{(3)}-\mathrm{O}\right)\right]$. Last peaks between 709 and $711 \mathrm{~cm}^{-1}$ represents the asymmetric stretching of four coordinate boron $\left[\nu_{\mathrm{as}}\left(\mathrm{B}_{(4)}-\mathrm{O}\right)\right]$.

According to the Raman spectrum, $v_{\mathrm{as}}\left(\mathrm{B}_{(3)}-\mathrm{O}\right)$ is formed between the peaks of $1392-1396$ and $1286 \mathrm{~cm}^{-1}$. The peaks between $881-979 \mathrm{~cm}^{-1}$ represents the $v_{\mathrm{s}}\left(\mathrm{B}_{(3)}-\mathrm{O}\right) \cdot v_{\text {as }}\left(\mathrm{B}_{(3)}-\mathrm{O}\right)$ is seen at the peak values between $807-848 \mathrm{~cm}^{-1}$. The characteristic peaks of magnesium borates, $v_{p}\left[\mathrm{~B}_{4} \mathrm{O}_{5}(\mathrm{OH})_{4}\right]^{2-}$ and $v_{p}\left[\mathrm{~B}_{5} \mathrm{O}_{6}(\mathrm{OH})_{4}\right]^{-}$are seen at 543 and $499 \mathrm{~cm}^{-1}$, respectively. The other peaks $\left(<417 \mathrm{~cm}^{-1}\right)$ are the bending of four coordinate boron $\left[\delta\left(\mathrm{B}_{(4)}-\mathrm{O}\right)\right]$.

SEM morphologies of the minerals are given in Figure 5. According to the results, mineral thicknesses of the $1: 1$ and $3: 2$ mole ratio minerals were changed between the 3.74$23.47 \mu \mathrm{m}$ and $5.05-16.82 \mu \mathrm{m}$, respectively, in $800^{\circ} \mathrm{C}$ reaction temperature. These particle thicknesses were decreased to $3.23-10.73 \mu \mathrm{m}$ at the mole ratio of $3: 2$ and increased to $4.69-$ $29.53 \mu \mathrm{m}$ at the mole ratio of $1: 1$ in $900^{\circ} \mathrm{C}$ reaction temperature. In $1000^{\circ} \mathrm{C}$ compared to $800^{\circ} \mathrm{C}$ reaction temperature the $1: 1$ mole ratio of minerals was decreased to $4.70-17.86 \mu \mathrm{m}$ and $3: 2$ mole ratio of minerals was decreased to $3.45-14.76 \mu \mathrm{m}$. 
TABLE 1: XRD crystal scores of the dehydrated magnesium borates produced by solid-state method.

\begin{tabular}{|c|c|c|c|c|c|c|c|c|c|c|c|c|c|c|c|c|}
\hline \multirow{3}{*}{ Temperature $\left({ }^{\circ} \mathrm{C}\right)$} & Time (min) & & & 30 & & & & & 60 & & & & & 240 & & \\
\hline & \multirow{2}{*}{ Product code } & \multicolumn{15}{|c|}{$\mathrm{M}: \mathrm{B}$ ratio $(\mathrm{mol} / \mathrm{mol})$} \\
\hline & & $2: 1$ & $3: 2$ & $1: 1$ & $1: 2$ & $1: 4$ & $2: 1$ & $3: 2$ & $1: 1$ & $1: 2$ & $1: 4$ & $2: 1$ & $3: 2$ & $1: 1$ & $1: 2$ & $1: 4$ \\
\hline \multirow{2}{*}{1000} & K & 59 & 61 & 58 & 47 & 38 & 53 & 62 & 58 & 44 & 35 & 57 & 61 & 58 & 52 & 33 \\
\hline & $\mathrm{MB}^{1}$ & 34 & 37 & 37 & 34 & 36 & 47 & 38 & 41 & 47 & 34 & 29 & 38 & 55 & 57 & 52 \\
\hline \multirow{3}{*}{900} & $\mathrm{~K}$ & 67 & 62 & 60 & 61 & 46 & 63 & 65 & 62 & 49 & 42 & 60 & 61 & 58 & 60 & 41 \\
\hline & $\mathrm{MB}^{1}$ & 10 & 18 & 18 & 24 & 13 & 12 & 35 & 21 & 26 & 16 & 13 & 19 & 31 & 13 & 13 \\
\hline & $\mathrm{MB}^{2}$ & - & - & - & 30 & 28 & - & - & 24 & 25 & 34 & 37 & - & - & 37 & 29 \\
\hline \multirow{7}{*}{800} & $\mathrm{~K}$ & 50 & 55 & 59 & 55 & 45 & 68 & 65 & 66 & 57 & 36 & 62 & 63 & 86 & 64 & 52 \\
\hline & $S^{1}$ & - & - & - & - & - & 3 & - & - & 16 & 19 & - & - & 14 & - & - \\
\hline & $S^{2}$ & - & - & - & - & - & - & - & - & - & - & - & 5 & - & - & - \\
\hline & $\mathrm{MB}^{1}$ & 2 & 3 & 11 & 12 & 6 & - & - & - & - & - & 5 & - & - & 13 & 5 \\
\hline & $\mathrm{MB}^{2}$ & - & - & - & - & 14 & - & - & - & - & 45 & - & - & - & - & 10 \\
\hline & $\mathrm{MB}^{3}$ & - & - & - & - & - & - & - & 11 & - & - & - & - & - & - & - \\
\hline & $\mathrm{MB}^{4}$ & - & - & - & - & - & - & 7 & - & - & - & - & - & - & - & - \\
\hline \multirow{5}{*}{700} & $S^{1}$ & & & & & & & & & & & - & - & 15 & 14 & - \\
\hline & $S^{2}$ & & & & & & & & & & & 6 & 12 & 12 & - & - \\
\hline & $\mathrm{MB}^{3}$ & & & & & & & & & & & - & 9 & - & - & - \\
\hline & $\mathrm{MB}^{4}$ & & & & & & & & & & & - & - & - & 8 & 7 \\
\hline & $\mathrm{P}$ & & & & & & & & & & & 85 & - & - & - & - \\
\hline \multirow{4}{*}{600} & $S^{1}$ & & & & & & & & & & & - & - & 6 & 13 & 11 \\
\hline & $S^{2}$ & & & & & & & & & & & 8 & 11 & - & - & - \\
\hline & $\mathrm{MB}^{4}$ & & & & & & & & & & & - & - & - & - & 16 \\
\hline & $\mathrm{P}$ & & & & & & & & & & & 85 & - & - & - & - \\
\hline
\end{tabular}

$\mathrm{M}: \mathrm{MgO}$

B: $\mathrm{B}_{2} \mathrm{O}_{3}$

$\mathrm{K}$ : kotoite, pdf no. $=01-075-1807, \mathrm{Mg}_{3}\left(\mathrm{BO}_{3}\right)_{2}$

$\mathrm{S}^{1}$ : suanite, pdf no. $=01-056-0531, \mathrm{Mg}_{2}\left(\mathrm{~B}_{2} \mathrm{O}_{5}\right)$

$\mathrm{S}^{2}$ : suanite, pdf no. $=01-073-2107, \mathrm{Mg}_{2}\left(\mathrm{~B}_{2} \mathrm{O}_{5}\right)$

$\mathrm{MB}^{1}$ : magnesium borate, pdf no. $=01-083-0625, \mathrm{Mg}_{2}\left(\mathrm{~B}_{2} \mathrm{O}_{5}\right)$

$\mathrm{MB}^{2}$ : magnesium borate, pdf no. $=00-031-0787, \mathrm{MgB}_{4} \mathrm{O}_{7}$

$\mathrm{MB}^{3}$ : magnesium borate, pdf no. $=01-073-2232, \mathrm{Mg}_{2} \mathrm{~B}_{2} \mathrm{O}_{5}$

$\mathrm{MB}^{4}$ : magnesium borate, pdf no. $=01-076-0666, \mathrm{MgO}\left(\mathrm{B}_{2} \mathrm{O}_{3}\right)_{2}$

$\mathrm{P}$ : periclase, $\mathrm{pdf}$ no. $=01-077-2179, \mathrm{MgO}$.

TABLE 2: Crystallographic data of synthesized dehydrated magnesium borates.

\begin{tabular}{|c|c|c|c|c|c|c|c|}
\hline Mineral name & Kotoite & Suanite & Suanite & $\begin{array}{l}\text { Magnesium } \\
\text { borate }\end{array}$ & $\begin{array}{l}\text { Magnesium } \\
\text { borate }\end{array}$ & $\begin{array}{l}\text { Magnesium } \\
\text { borate }\end{array}$ & $\begin{array}{l}\text { Magnesium } \\
\text { borate }\end{array}$ \\
\hline pdf no. & 01-075-1807 & 01-056-0531 & 01-073-2107 & 01-083-0625 & 00-031-0787 & 01-073-2232 & 01-076-0666 \\
\hline Chemical formula & $\mathrm{Mg}_{3}\left(\mathrm{BO}_{3}\right)_{2}$ & $\mathrm{Mg}_{2}\left(\mathrm{~B}_{2} \mathrm{O}_{5}\right)$ & $\mathrm{Mg}_{2}\left(\mathrm{~B}_{2} \mathrm{O}_{5}\right)$ & $\mathrm{Mg}_{2}\left(\mathrm{~B}_{2} \mathrm{O}_{5}\right)$ & $\mathrm{MgB}_{4} \mathrm{O}_{7}$ & $\mathrm{Mg}_{2} \mathrm{~B}_{2} \mathrm{O}_{5}$ & $\mathrm{MgO}\left(\mathrm{B}_{2} \mathrm{O}_{3}\right)_{2}$ \\
\hline $\begin{array}{l}\text { Molecular weight } \\
(\mathrm{g} / \mathrm{mol})\end{array}$ & 190.53 & 150.23 & 150.23 & 150.23 & 179.54 & 150.23 & 179.54 \\
\hline Crystal system & Orthorhombic & Monoclinic & Monoclinic & Anorthic & Orthorhombic & Anorthic & Orthorhombic \\
\hline Space group & Pnmn & $\mathrm{P} 21 / \mathrm{c}$ & $\mathrm{P} 21 / \mathrm{c}$ & P-1 & $\mathrm{Pbca}$ & P-1 & Pbca \\
\hline$a(\AA)$ & 5.398 & 9.1970 & 12.100 & 6.149 & 5.896 & 6.187 & 13.730 \\
\hline$b(\AA)$ & 8.416 & 3.1228 & 3.120 & 9.221 & 13.729 & 9.219 & 7.970 \\
\hline$c(\AA)$ & 4.497 & 12.3030 & 9.360 & 3.121 & 7.956 & 3.119 & 8.620 \\
\hline$\alpha\left({ }^{\circ}\right)$ & 90.00 & 90.00 & 90.00 & 90.29 & 90.00 & 90.40 & 90.00 \\
\hline$\beta\left(^{\circ}\right)$ & 90.00 & 104.26 & 104.33 & 92.23 & 90.00 & 92.13 & 90.00 \\
\hline$\gamma\left({ }^{\circ}\right)$ & 90.00 & 90.00 & 90.00 & 104.30 & 90.00 & 104.32 & 90.00 \\
\hline$z$ & 2.00 & 4.00 & 4.00 & 2.00 & 8.00 & 2.00 & 8.00 \\
\hline Density $\left(\mathrm{g} \cdot \mathrm{cm}^{-3}\right)$ & 3.10 & 2.91 & 2.91 & 2.91 & 2.54 & 2.90 & 2.53 \\
\hline
\end{tabular}




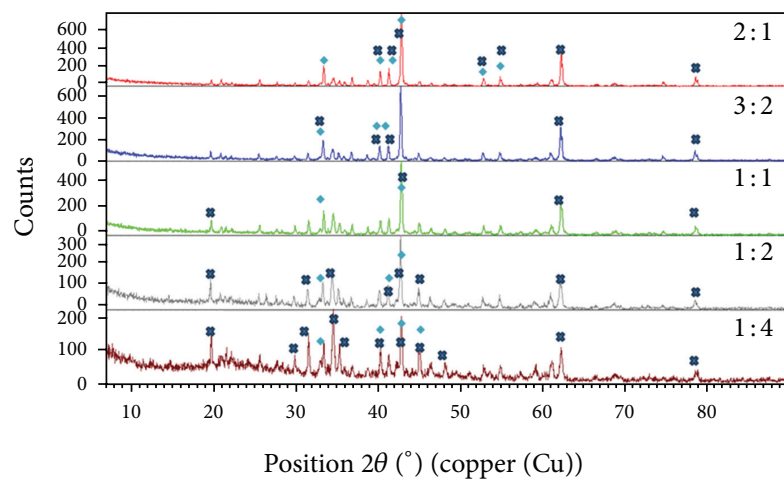

(a)

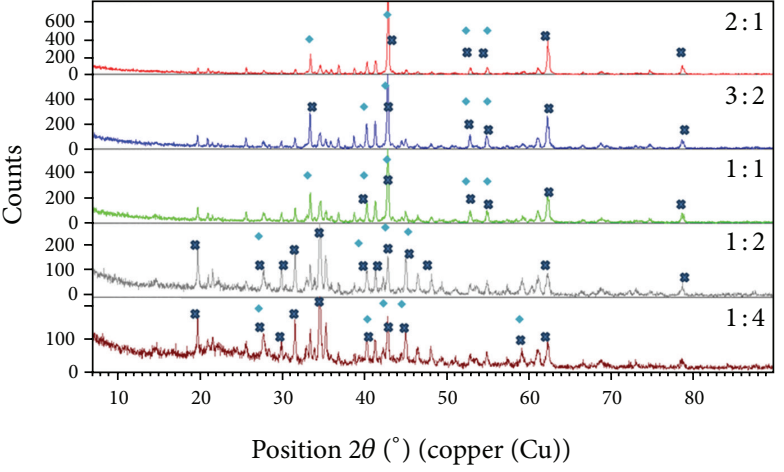

(b)

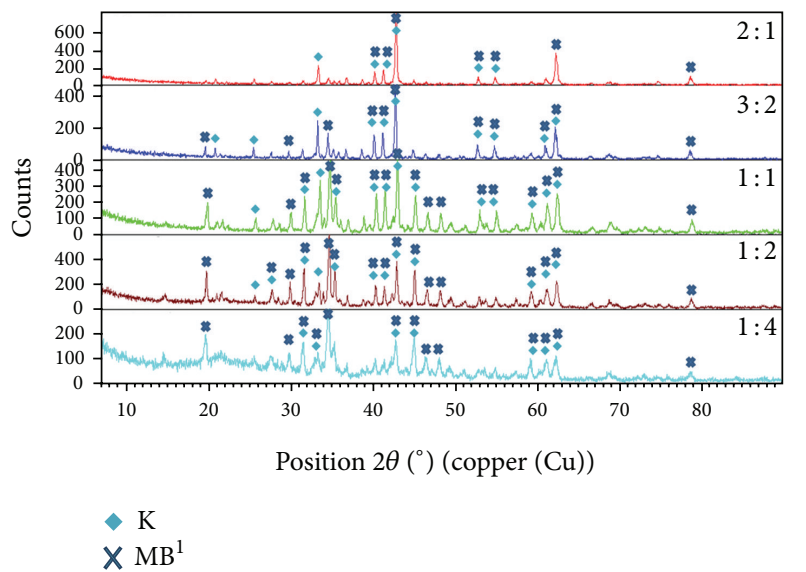

(c)

FIGURE 1: XRD patterns of the synthesized dehydrated magnesium borate minerals at $1000^{\circ} \mathrm{C}$. (a) 30 minutes, (b) 60 minutes, and (c) 240 minutes.

The lowest particle sizes were seen on 1:1 mole ratio at the reaction temperature of $1000^{\circ} \mathrm{C}$ and $3: 2$ mole ratio at the reaction temperature of $900^{\circ} \mathrm{C}$.

The $\mathrm{B}_{2} \mathrm{O}_{3}$ results of the dehydrated magnesium borates were given in Table 3 . Since the XRD crystal scores of the minerals at 240 minutes are higher than the other reaction times, only these minerals $\mathrm{B}_{2} \mathrm{O}_{3}$ percentages were calculated. And it is seen from the experimental results the $\mathrm{B}_{2} \mathrm{O}_{3}$ contents were similar to the theoretical contents of the kotoite and suanite $\mathrm{B}_{2} \mathrm{O}_{3}$ contents which are 36.54 and $46.34 \%$, respectively. For example theoretically ((4) and (5)), at the mole ratio of $1: 1$ suanite formation was higher and at the mole ratio of $3: 2$ kotoite formation was higher than the other minerals. At the mole ratio of $3: 2$ and temperatures of $800^{\circ} \mathrm{C}, 900^{\circ} \mathrm{C}$ and $1000^{\circ} \mathrm{C}$, the $\mathrm{B}_{2} \mathrm{O}_{3}$ ratios were seen as $30.12,36.25$ and $37.51 \%$ respectively which are nearly equal to the theoretical kotoite $\mathrm{B}_{2} \mathrm{O}_{3}$ ratio of $36.54 \%$. Similarly at the mole ratio of $1: 1$ and temperatures of $800^{\circ} \mathrm{C}, 900^{\circ} \mathrm{C}$, and $1000^{\circ} \mathrm{C}$, the $\mathrm{B}_{2} \mathrm{O}_{3}$ ratios were seen as $44.99,40.62$, and $42.56 \%$, respectively, which are nearly equal to the theoretical suanite $\mathrm{B}_{2} \mathrm{O}_{3}$ ratio of $46.34 \%$. Since the obtained minerals have at least two phases, the $\mathrm{B}_{2} \mathrm{O}_{3}$ contents can be varied from each other

$$
\begin{aligned}
& 2 \mathrm{MgO}+\mathrm{B}_{2} \mathrm{O}_{3} \longrightarrow \mathrm{Mg}_{2} \mathrm{~B}_{2} \mathrm{O}_{5} \text { (Suanite) } \\
& 3 \mathrm{MgO}+\mathrm{B}_{2} \mathrm{O}_{3} \longrightarrow \mathrm{Mg}_{3} \mathrm{~B}_{2} \mathrm{O}_{6} \text { (Kotoite) }
\end{aligned}
$$

Reaction yields were calculated for the mole ratios of $3: 2$ and $1: 1$. The minerals obtained at those ratios were $\mathrm{Mg}_{2} \mathrm{~B}_{2} \mathrm{O}_{5}$ and $\mathrm{Mg}_{3} \mathrm{~B}_{2} \mathrm{O}_{6}$, so the minimum reaction yields were calculated using the $\mathrm{Mg}_{3} \mathrm{~B}_{2} \mathrm{O}_{6}$ molecular weight of $190.53 \mathrm{~g} / \mathrm{mol}$. The results are given in Table 4 . According to the reaction yields obtained $3: 2$ mole ratio $(82-88 \%)$ is greater than the 1:1 mole ratio (46-53\%). Reaction yields of dehydrated magnesium borates were changed with little amounts according to the temperature increase and reaction temperature. So reaction temperature and reaction time only changed the crystal structures and scores. The highest reaction yield was seen at $800^{\circ} \mathrm{C}, 240$ minutes of reaction time, and $3: 2$ mole ratio product with a value of $88 \%$.

3.3. Neutron Transmission Results. The neutron transmission values and total macroscopic cross-sections of the dehydrated magnesium borate minerals synthesized by solidstate method using the $\mathrm{MgO}$ and $\mathrm{B}_{2} \mathrm{O}_{3}$ with $1000^{\circ} \mathrm{C}$ reaction temperature, 240 minutes of reaction time and $1: 1$ and $3: 2$ mole ratios were shown in Table 5.

From the results obtained it was seen that the $3: 2$ mole ratio synthesized minerals neutron transmission values were lower than the 1:1 mole ratio synthesized minerals. The difference between the minerals neutron transmission values can be explained by the crystal score differences obtained from XRD results. "K" crystal scores of synthesized minerals 


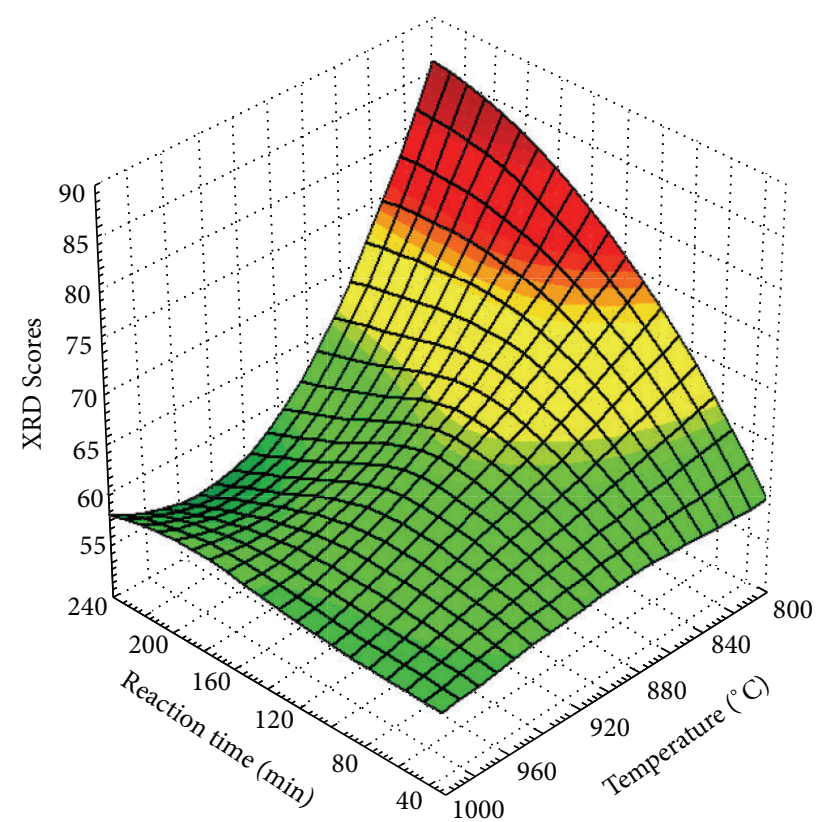

(a)

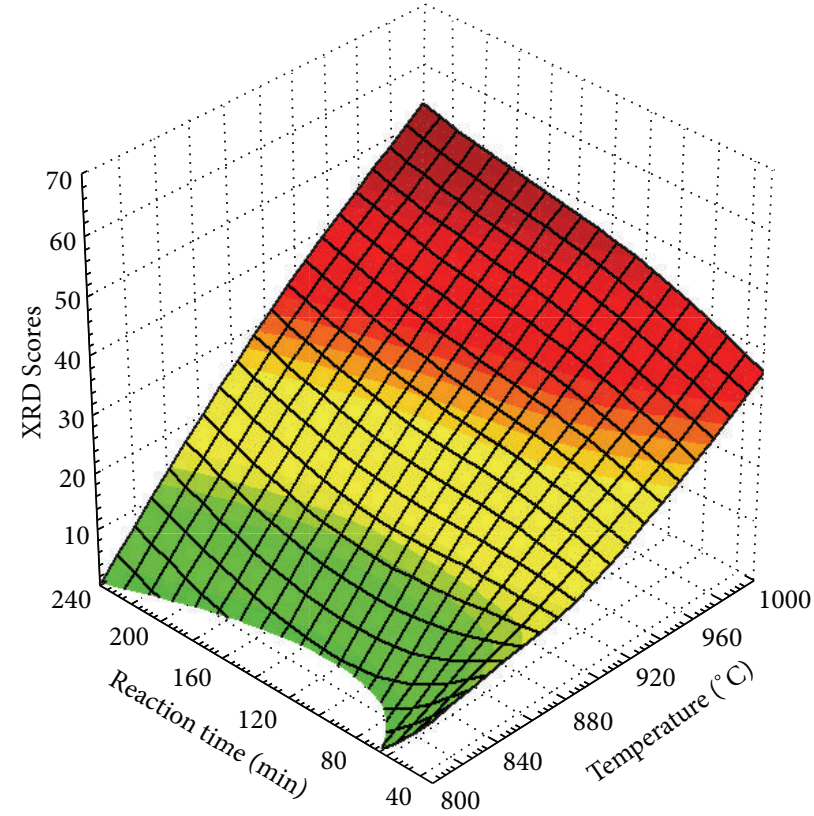

(c)

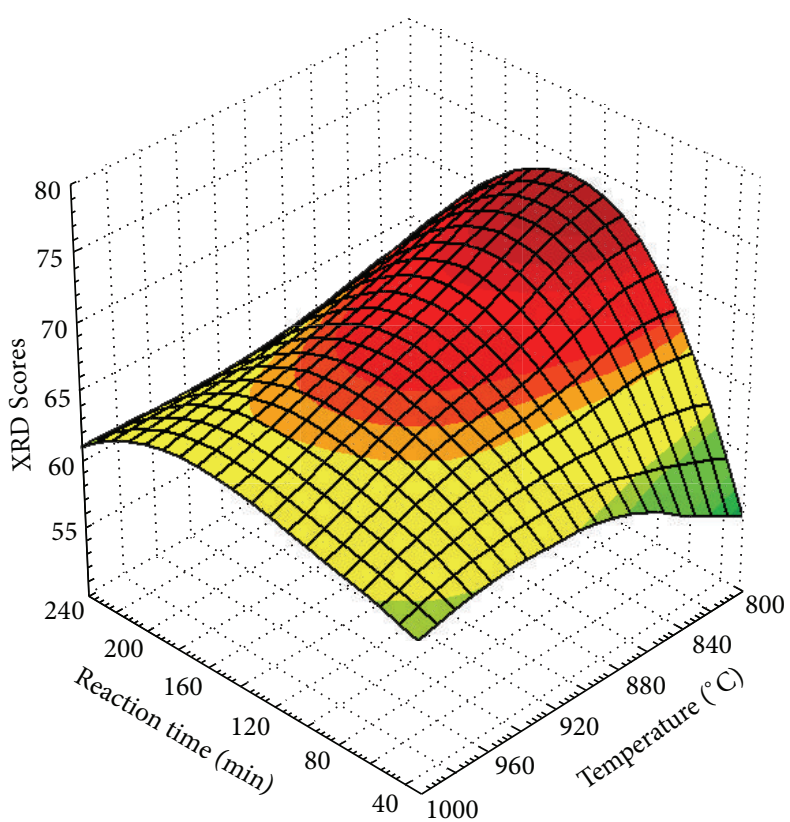

(b)

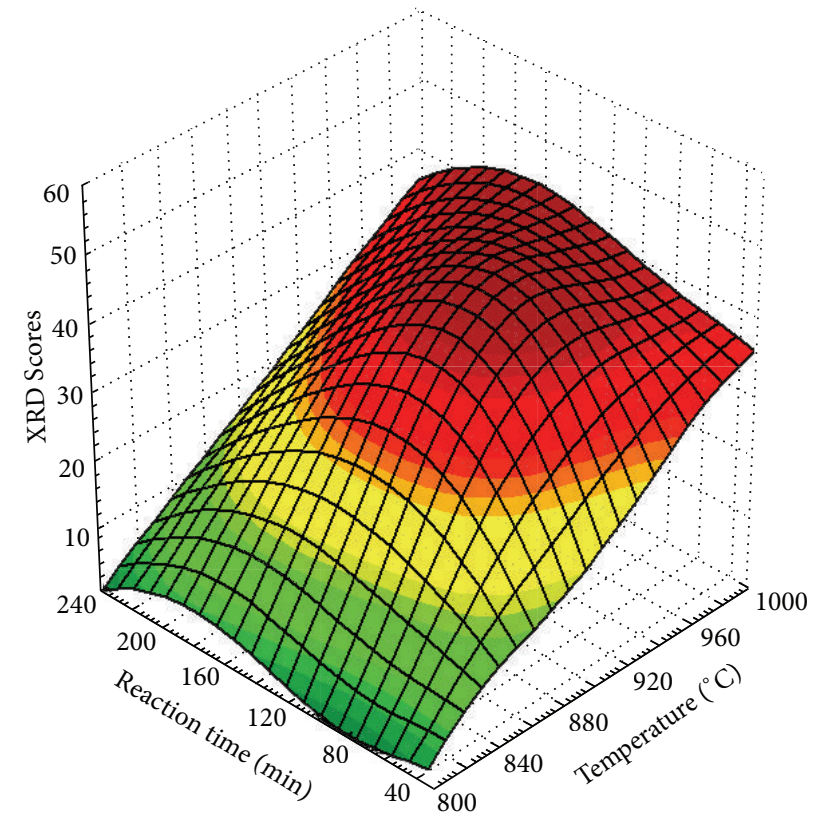

(d)

FIGURE 2: Three dimensional model graph of dehydrated magnesium borate formation; (a) K (1:1), (b) K (3:2), (c) MB ${ }^{1}(1: 1)$, (d) MB ${ }^{1}(3: 2)$.

were 61 and 58 for the $3: 2$ and $1: 1$ mole ratios, respectively. By the same manner " $\mathrm{MB}^{3}$ " crystal scores of synthesized minerals were 38 and 55 for the $3: 2$ and $1: 1$ mole ratios, respectively. Closed formula of the " $\mathrm{K}$ " is " $\mathrm{Mg}_{3}\left(\mathrm{BO}_{3}\right)_{2}$ " and that for " $\mathrm{MB}^{3 \text { " }}$ is " $\mathrm{Mg}_{2}\left(\mathrm{~B}_{2} \mathrm{O}_{5}\right)$." So at the mole ratio of $3: 2$ $\mathrm{Mg}_{3}\left(\mathrm{BO}_{3}\right)_{2}$ score was higher than that $\mathrm{Mg}_{2}\left(\mathrm{~B}_{2} \mathrm{O}_{5}\right)$, which means that the " $\mathrm{K}$ " is the major phase in this synthesis. Different formation was seen on 1:1 mole ratio where the $\mathrm{Mg}_{3}\left(\mathrm{BO}_{3}\right)_{2}$ crystal score was nearly equal to the $\mathrm{Mg}_{2}\left(\mathrm{~B}_{2} \mathrm{O}_{5}\right)$

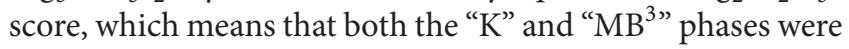

obtained equally. " $\mathrm{K}$ " phase has an additional structure of "MgO" than the " $\mathrm{MB}^{3 \text { " }}$ phase as seen on

$$
\mathrm{MgO}+\mathrm{Mg}_{2}\left(\mathrm{~B}_{2} \mathrm{O}_{5}\right) \longrightarrow \mathrm{Mg}_{3}\left(\mathrm{BO}_{3}\right)_{2}
$$

The $3: 2$ mole ratio neutron transmission value $(0.618-$ $0.655)$ is lower than the $1: 1$ mole ratio neutron transmission value $(0.772-0.843)$. So better results were obtained where "K" was the major phase and has high crystal score (61) than $1: 1$ ratio (58). Also neutron transmission values and total 


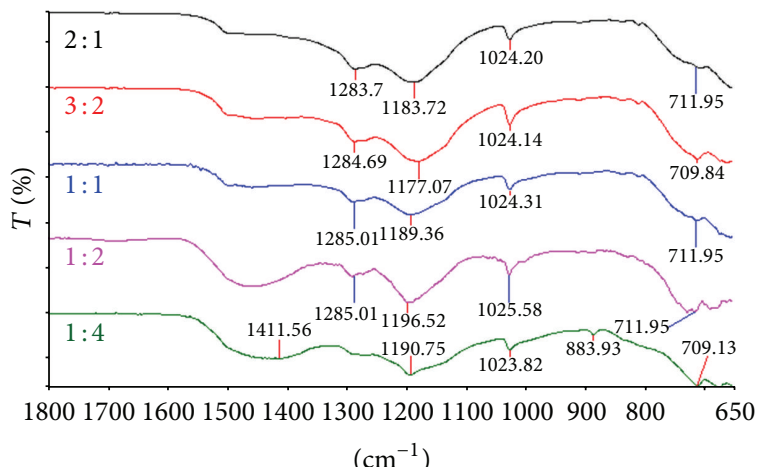

FIGURE 3: FT-IR spectrum of the synthesized dehydrated magnesium borate minerals at $1000^{\circ} \mathrm{C}$ and 240 minutes of reaction time.

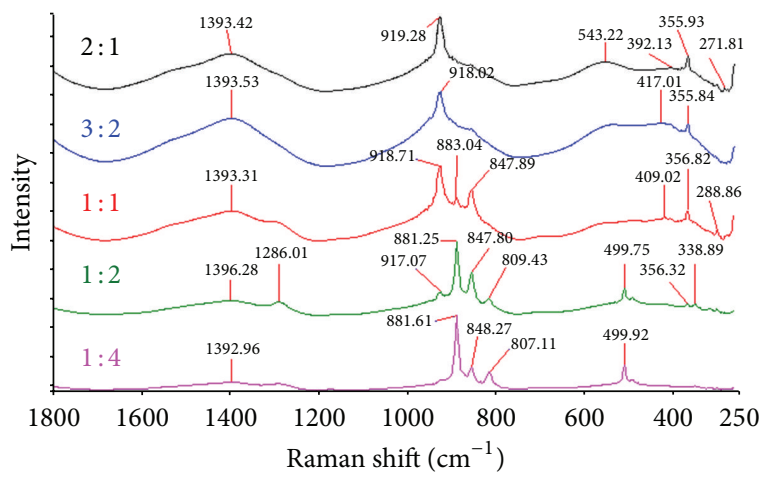

FIGURE 4: Raman spectrum of the synthesized dehydrated magnesium borate minerals at $1000^{\circ} \mathrm{C}$ and 240 minutes of reaction time.

macroscopic sections were decreased with increasing pellet thicknesses.

\section{Conclusions}

In this study, using the raw materials of $\mathrm{MgO}$ and $\mathrm{B}_{2} \mathrm{O}_{3}$, the synthesis of dehydrated magnesium borates was studied. The solid-state method was used with varying both of reaction temperatures at $600^{\circ} \mathrm{C}$ to $1000^{\circ} \mathrm{C}$ and reaction times of 30 minutes to 240 minutes. XRD results showed that the formation of dehydrated magnesium borates was started at a temperature of $600^{\circ} \mathrm{C}$, and the " $\mathrm{K}$ " formation was started at a temperature of $800^{\circ} \mathrm{C}$, and the highest crystal scores are obtained at the reaction time of 240 minutes and $800^{\circ} \mathrm{C}$ reaction temperature and higher. From the experiments, the formation of kotoite $\left[\mathrm{Mg}_{3}\left(\mathrm{BO}_{3}\right)_{2}\right]$, two types of suanite $\left[\mathrm{Mg}_{2}\left(\mathrm{~B}_{2} \mathrm{O}_{5}\right)\right]$, and four different formulated dehydrated magnesium borates $\left[\mathrm{Mg}_{2}\left(\mathrm{~B}_{2} \mathrm{O}_{5}\right), \mathrm{MgB}_{4} \mathrm{O}_{7}, \mathrm{Mg}_{2} \mathrm{~B}_{2} \mathrm{O}_{5}\right.$, $\left.\mathrm{MgO}\left(\mathrm{B}_{2} \mathrm{O}_{3}\right)_{2}\right]$ were seen.

FT-IR and Raman spectrum of the synthesized minerals showed the characteristic peaks of the magnesium borates both in infrared and visible regions. The lowest particle size on 1:1 mole ratio determined by the SEM analysis was seen between 4.70 and $17.86 \mu \mathrm{m}$ at the reaction temperature of $1000^{\circ} \mathrm{C}$. At the $3: 2$ mole ratio the lowest particle size was seen between 3.45 and $14.76 \mu \mathrm{m}$ at the reaction temperature
TABLE 3: Calculated $\mathrm{B}_{2} \mathrm{O}_{3}$ contents of the synthesized dehydrated magnesium borate minerals.

\begin{tabular}{|c|c|c|}
\hline Temperature $\left({ }^{\circ} \mathrm{C}\right)$ & $\mathrm{M}: \mathrm{B}$ ratio & $\mathrm{B}_{2} \mathrm{O}_{3}$ contents $(\%)$ \\
\hline \multirow{5}{*}{600} & $2: 1$ & $26.63 \pm 0.27$ \\
\hline & $3: 2$ & $30.03 \pm 0.14$ \\
\hline & $1: 1$ & $36.54 \pm 0.55$ \\
\hline & $1: 2$ & $44.70 \pm 0.55$ \\
\hline & $1: 4$ & $43.44 \pm 0.27$ \\
\hline \multirow{5}{*}{700} & $2: 1$ & $30.03 \pm 0.14$ \\
\hline & $3: 2$ & $33.52 \pm 0.69$ \\
\hline & $1: 1$ & $28.28 \pm 0.41$ \\
\hline & $1: 2$ & $28.37 \pm 1.10$ \\
\hline & $1: 4$ & $28.28 \pm 0.41$ \\
\hline \multirow{5}{*}{800} & $2: 1$ & $32.46 \pm 0.27$ \\
\hline & $3: 2$ & $30.12 \pm 3.57$ \\
\hline & $1: 1$ & $44.99 \pm 0.41$ \\
\hline & $1: 2$ & $50.14 \pm 3.85$ \\
\hline & $1: 4$ & $54.42 \pm 2.75$ \\
\hline \multirow{5}{*}{900} & $2: 1$ & $31.68 \pm 0.27$ \\
\hline & $3: 2$ & $36.25 \pm 0.14$ \\
\hline & $1: 1$ & $40.62 \pm 4.67$ \\
\hline & $1: 2$ & $49.17 \pm 0.27$ \\
\hline & $1: 4$ & $55.97 \pm 1.10$ \\
\hline \multirow{5}{*}{1000} & $2: 1$ & $28.96 \pm 4.67$ \\
\hline & $3: 2$ & $37.51 \pm 0.27$ \\
\hline & $1: 1$ & $42.56 \pm 0.27$ \\
\hline & $1: 2$ & $47.61 \pm 0.82$ \\
\hline & $1: 4$ & $53.93 \pm 1.51$ \\
\hline
\end{tabular}

TABLE 4: Minimum reaction yields (\%) based on "K."

\begin{tabular}{lcccc}
\hline \multirow{2}{*}{$\begin{array}{l}\text { Reaction } \\
\text { temperature }\left({ }^{\circ} \mathrm{C}\right)\end{array}$} & M : B ratio & \multicolumn{3}{c}{ Minimum reaction yield (\%) } \\
& & 30 min & 60 min & 240 min \\
\hline \multirow{2}{*}{800} & $3: 2$ & 84 & 84 & 88 \\
& $1: 1$ & 52 & 50 & 49 \\
\hline \multirow{2}{*}{900} & $3: 2$ & 84 & 82 & 84 \\
& $1: 1$ & 53 & 51 & 53 \\
\hline \multirow{2}{*}{1000} & $3: 2$ & 85 & 83 & 84 \\
& $1: 1$ & 53 & 46 & 53 \\
\hline
\end{tabular}

TABLE 5: Neutron transmission values and the total macroscopic sections of the dehydrated magnesium borate minerals.

\begin{tabular}{lccc}
\hline M : B ratio & $x(\mathrm{~cm})$ & $I / I_{0}$ & $\Sigma_{t}\left(\mathrm{~cm}^{-1}\right)$ \\
\hline \multirow{3}{*}{$3: 2$} & 0.55 & $0.655 \pm 0.0266$ & $0.769 \pm 0.0342$ \\
& 0.75 & $0.626 \pm 0.0298$ & $0.624 \pm 0.0309$ \\
& 1.25 & $0.618 \pm 0.0293$ & $0.385 \pm 0.0185$ \\
$1: 1$ & 0.55 & $0.843 \pm 0.0254$ & $0.311 \pm 0.0109$ \\
& 0.75 & $0.813 \pm 0.0307$ & $0.276 \pm 0.0110$ \\
& 1.25 & $0.772 \pm 0.0402$ & $0.207 \pm 0.0109$ \\
\hline
\end{tabular}

of $900^{\circ} \mathrm{C}$. Obtained $\mathrm{B}_{2} \mathrm{O}_{3}$ contents were calculated and seen with a mutual agreement with the theoretical kotoite and 


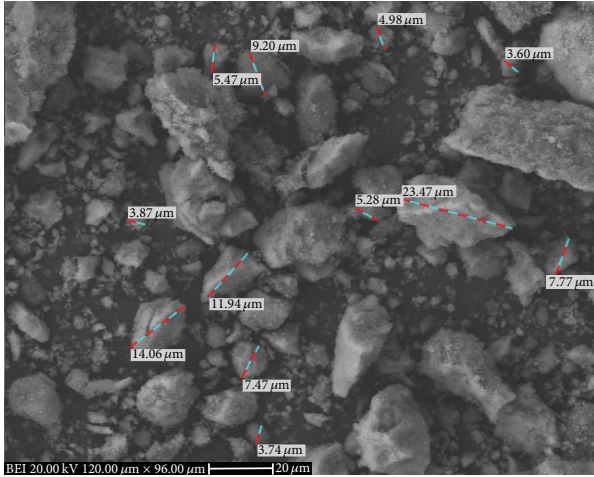

(a)

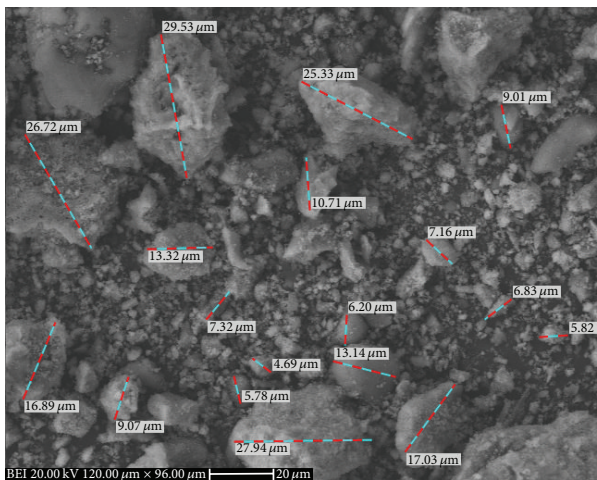

(c)

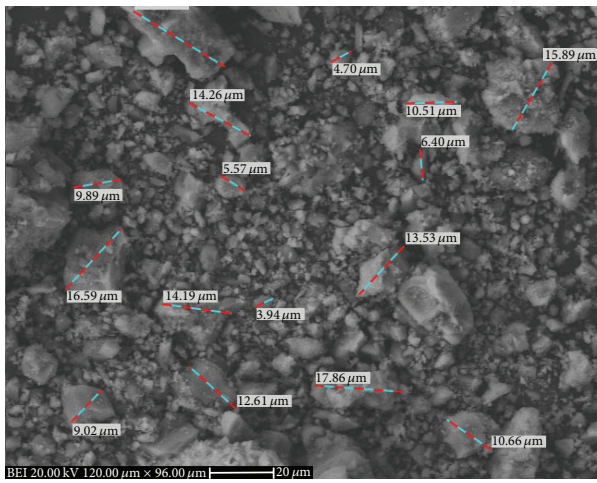

(e)

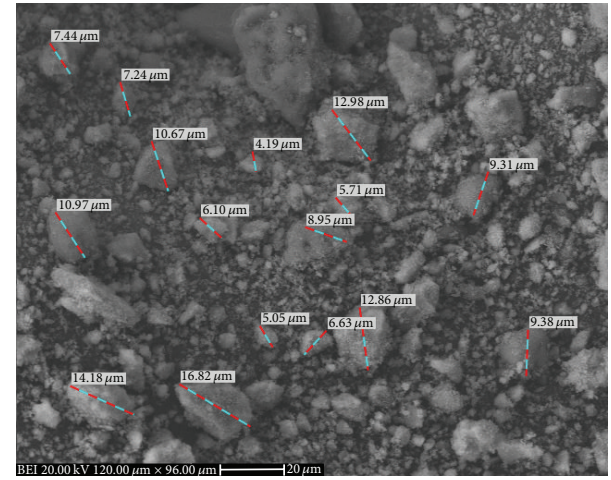

(b)

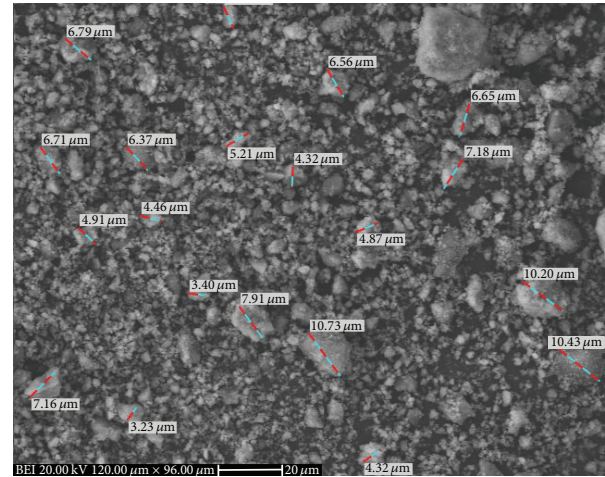

(d)

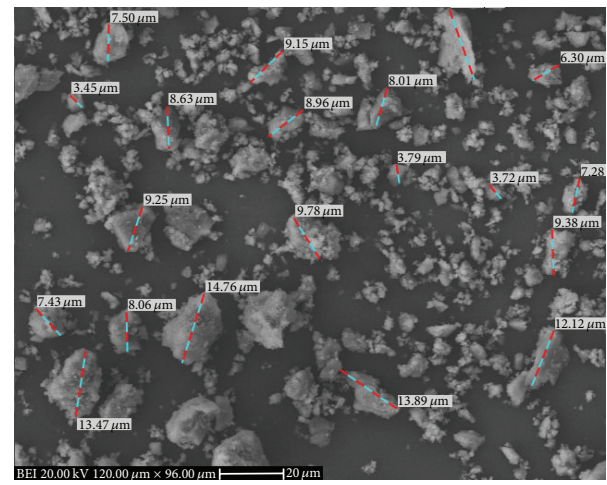

(f)

FIGURE 5: SEM photos of the synthesized dehydrated magnesium borate minerals, magnification of $1000 \mathrm{x}$; (a) $800^{\circ} \mathrm{C}-1: 1$, (b) $800^{\circ} \mathrm{C}-3: 2$, (c) $900^{\circ} \mathrm{C}-1: 1$, (d) $900^{\circ} \mathrm{C}-3: 2$, (e) $1000^{\circ} \mathrm{C}-1: 1$, and (f) $1000^{\circ} \mathrm{C}-3: 2$.

suanite contents. Reaction yields were changed between 82 and $88 \%$ in $3: 2$ mole ratio and 46 and 53\% in $1: 1$ mole ratio.

From the neutron transmission experiments, it was seen that where " $K$ " was the major phase less neutron transmission values were obtained. So it can be said that the " $K$ " type dehydrated magnesium borates are better than the " $\mathrm{MB}^{1}$ " type dehydrated magnesium borates against neutron radiation.

\section{Acknowledgment}

This study was supported by the "Office of Scientific Research Project Coordination" in Yildiz Technical University with the Project no. of "2012-07-01-KAP03."

\section{References}

[1] S. Li, X. Fang, J. Leng, H. Shen, Y. Fan, and D. Xu, "A new route for the synthesis of $\mathrm{Mg}_{2} \mathrm{~B}_{2} \mathrm{O}_{5}$ nanorods by mechano-chemical and sintering process," Materials Letters, vol. 64, no. 2, pp. 151153, 2010.

[2] E. M. Elssfah, A. Elsanousi, J. Zhang, H. S. Song, and C. Tang, "Synthesis of magnesium borate nanorods," Materials Letters, vol. 61, no. 22, pp. 4358-4361, 2007.

[3] E. G. Baker, "Boron zinc oxide and boron magnesium oxide catalysts for conversion of hydrocarbons," US Patent no: 2,889,266, 1959.

[4] C. Furetta, G. Kitis, P. S. Weng, and T. C. Chu, "Thermoluminescence characteristics of $\mathrm{MgB}_{4} \mathrm{O}_{7}$ : Dy,Na," Nuclear Instruments 
and Methods in Physics Research, Section A, vol. 420, no. 3, pp. 441-445, 1999.

[5] A. M. Alper and R. N. Corning, "MgO- $\mathrm{B}_{2} \mathrm{O}_{3}$ fused cast refractory," 1967, US Patent no: 3,337,353.

[6] S. H. Kim, K. H. Lee, B. S. Seong, G.-H. Kim, J. S. Kim, and Y. S. Yoon, "Synthesis and structural properties of lithium titanium oxide powder," Korean Journal of Chemical Engineering, vol. 23, no. 6, pp. 961-964, 2006.

[7] Y. Li, Z. Fan, J. G. Lu, and R. P. H. Chang, "Synthesis of magnesium borate $\left(\mathrm{Mg}_{2} \mathrm{~B}_{2} \mathrm{O}_{5}\right)$ nanowires by chemical vapor deposition method," Chemistry of Materials, vol. 16, no. 13, pp. 2512-2514, 2004.

[8] W. Zhu, G. Li, Q. Zhang, L. Xiang, and S. Zhu, "Hydrothermal mass production of $\mathrm{MgBO}_{2}(\mathrm{OH})$ nanowhiskers and subsequent thermal conversion to $\mathrm{Mg}_{2} \mathrm{~B}_{2} \mathrm{O}_{5}$ nanorods for biaxially oriented polypropylene resins reinforcement," Powder Technology, vol. 203, no. 2, pp. 265-271, 2010.

[9] U. Došler, M. M. Kržmanc, and D. Suvorov, "The synthesis and microwave dielectric properties of $\mathrm{Mg}_{3} \mathrm{~B}_{2} \mathrm{O}_{6}$ and $\mathrm{Mg}_{2} \mathrm{~B}_{2} \mathrm{O}_{5}$ ceramics," Journal of the European Ceramic Society, vol. 30, no. 2, pp. 413-418, 2010.

[10] A. F. Qasrawi, T. S. Kayed, A. Mergen, and M. Gürü, "Synthesis and characterization of $\mathrm{Mg}_{2} \mathrm{~B}_{2} \mathrm{O}_{5}$," Materials Research Bulletin, vol. 40, no. 4, pp. 583-589, 2005.

[11] J. Zhang, Z. Li, and B. Zhang, "Formation and structure of single crystalline magnesium borate $\left(\mathrm{Mg}_{3} \mathrm{~B}_{2} \mathrm{O}_{6}\right)$ nanobelts," Materials Chemistry and Physics, vol. 98, no. 2-3, pp. 195-197, 2006.

[12] Y. Zeng, H. Yang, W. Fu et al., "Synthesis of magnesium borate $\left(\mathrm{Mg}_{2} \mathrm{~B}_{2} \mathrm{O}_{5}\right)$ nanowires, growth mechanism and their lubricating properties," Materials Research Bulletin, vol. 43, no. 8-9, pp. 2239-2247, 2008.

[13] E. M. Derun and A. S. Kipcak, "Characterization of some boron minerals against neutron shielding and 12 year performance of neutron permeability," Journal of Radioanalytical and Nuclear Chemistry, vol. 292, no. 2, pp. 871-878, 2012.

[14] S. I. Bhuiyan, F. U. Ahmed, A. S. Mollah, and M. A. Rahman, "Studies of the neutron transport and shielding properties of locally developed shielding material: poly-boron," Health Physics, vol. 57, no. 5, pp. 819-824, 1989.

[15] M. Adib and M. Kilany, "On the use of bismuth as a neutron filter," Radiation Physics and Chemistry, vol. 66, no. 2, pp. 81-88, 2003.

[16] S. E. Gwaily, M. M. Badawy, H. H. Hassan, and M. Madani, "Natural rubber composites as thermal neutron radiation shields-I. $\mathrm{B}_{4} \mathrm{C} / \mathrm{NR}$ composites," Polymer Testing, vol. 21, no. 2, pp. 129-133, 2002.

[17] M. Celli, F. Grazzi, and M. Zoppi, "A new ceramic material for shielding pulsed neutron scattering instruments," Nuclear Instruments and Methods in Physics Research, Section A, vol. 565, no. 2, pp. 861-863, 2006.

[18] D. L. Chichester and B. W. Blackburn, "Radiation fields from neutron generators shielded with different materials," Nuclear Instruments and Methods in Physics Research, Section B, vol. 261, no. 1-2, pp. 845-849, 2007.

[19] A. S. Kipcak, The Investigation of the Usability of Boron Minerals As a Neutron Shielding Material Yildiz Technical University [Ph.D. thesis], 2009, (Turkish).

[20] A. S. Kipcak, D. Yilmaz Baysoy, E. Moroydor Derun, and S. Piskin, The Evaluation of the Neutron Radiation Absorption Capacities of Inderite Minerals, vol. 1 of 2011 Research Bulletin of the Australian Institute of High Energetic Materials, 2011.
[21] A. S. Kipcak, D. Yilmaz Baysoy, E. Moroydor Derun, and S. Piskin, Characterization of the Kurnacovite Mineral and Its Absorption Behavior due to Neutron Radiation, vol. 1 of 2011 Research Bulletin of the Australian Institute of High Energetic Materials, 2011.

[22] E. Moroydor Derun, A. S. Kipcak, F. T. Senberber, and M. Sari Yilmaz, "Characterization and thermal dehydration kinetics of admontite mineral hydrothermally synthesized from magnesium oxide and boric acid precursor," Research on Chemical Intermediates.

[23] H. S. Fogler, Element of Chemical Reaction Engineering, Prentice-Hall, Englewood Cliffs, NJ, USA, 3rd edition, 1999. 

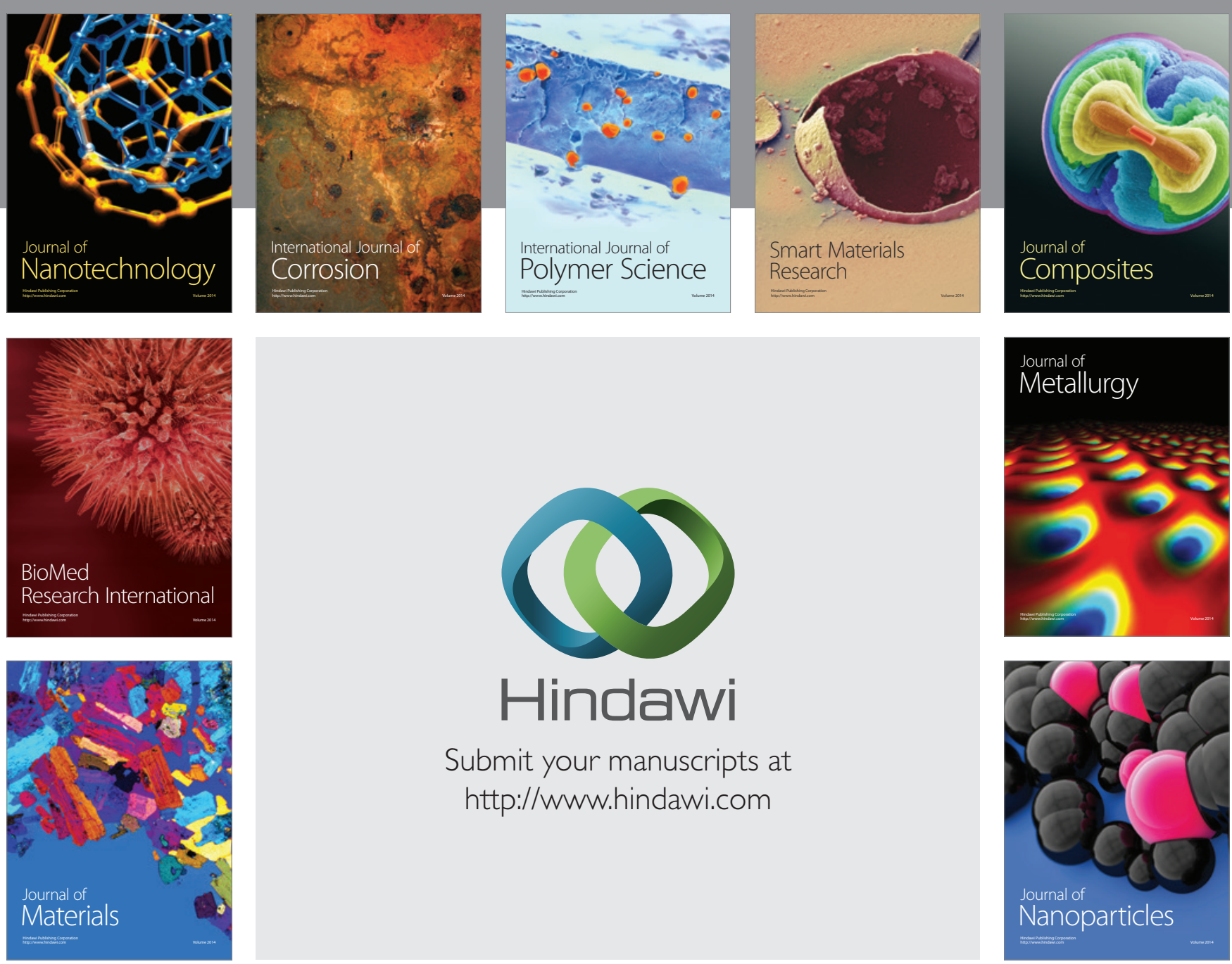

Submit your manuscripts at http://www.hindawi.com
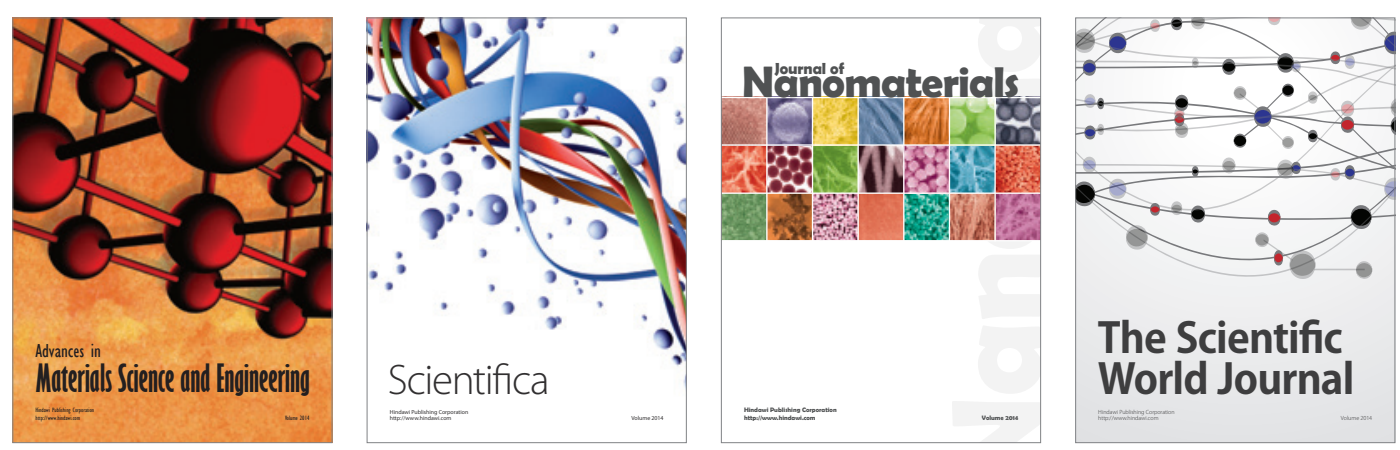

\section{The Scientific World Journal}
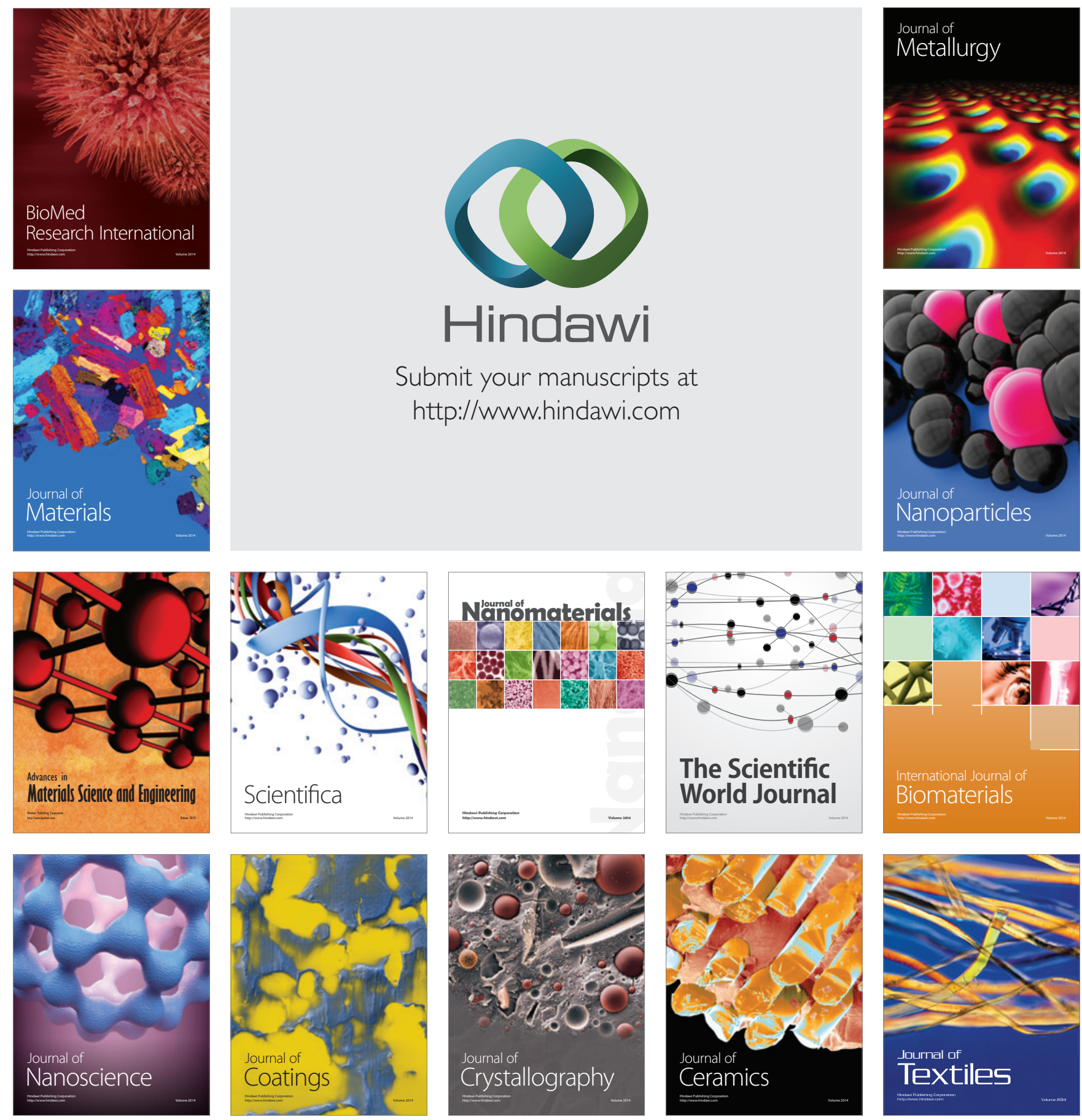